\section{The Influence of Political Connections on the Cost of Capital and the Performance of Companies Listed on B3}

\author{
Jaison Caetano da Silva ${ }^{\dagger}$ \\ Universidade do Vale do Itajaí, Biguacu, SC, Brazil \\ Wlamir Gonçalves Xavier ${ }^{\Omega}$ \\ Eastern New Mexico University, Portales, New Mexico, Estados Unidos \\ Cinara Gambirage $¥$ \\ FURB - Universidade Regional de Blumenau, Blumenau, SC, Brazil \\ Silvio Parodi Oliveira Camilo ${ }^{\ddagger}$ \\ UNESC - Universidade Extremo Sul Catarinense, Criciuma, SC, Brazil
}

\begin{abstract}
The theory holds that in emerging economies, such as the Brazilian one, companies seek to strengthen ties with governmental and institutional actors in order to improve their performance. From the theoretical perspective of the Institutional Theory, this study intends to contribute to previous research, integrating the fields of strategy and finance, investigating the influence of political connections, through campaign donations, the cost of capital and the performance of listed companies on B3. We worked with panel data for data analysis on the period ranging from 1998 to 2016. Our findings do not corroborate the theoretical and intuitive prediction that "crony capitalism" reduces the cost of capital and improves the performance of companies, since we did not obtain empirical evidence that allows affirming that the effect of donations on the cost of capital and the performance of connected companies is different from zero.
\end{abstract}

Keywords: Cost of Capital, Performance, Political Connections, Campaign Donations, Corruption.

\section{INTRODUCTION}

The government, as an important actor in the external environment and with a prominent role in the economy, is a provider and controller of resources. In addition, it deliberates on public policies and affects, directly or indirectly, companies of different productive segments (CAMILO; MARCON; BANDEIRA-DE-MELLO, 2012). Therefore, companies can develop strategies in order to connect with the government in order to obtain and preserve resources, as well as influencing public decisions and policies (HILLMAN; HITT, 1999). These political connections can play a relevant role in companies, regardless of the economy in which they are inserted, and the success or failure of organizations that use this strategy have led many researchers to study the subject in order to measure the value of such connections in the business world (HOUSTONet al., 2014).

In the present study, we assume that the political connections contribute with the companies in order to obtain financial resources
Corresponding author:

${ }^{\dagger}$ Universidade do Vale do Itajaí, Biguaçu, SC, Brazil

E-mail: jaisoncsilva@hotmail.com

$\Omega$ Eastern New Mexico University, Portales,

New Mexico, Estados Unidos

E-mail: wlamirxavier@gmail.com

$¥$ FURB - Universidade Regional de

Blumenau, Blumenau, SC, Brazil

E-mail: cinara@uniarp.edu.br

‡ UNESC - Universidade Extremo Sul

Catarinense, Criciúma, SC, Brazil

E-mail: parodi@unesc.net

Received: 03/09/2017.

Revised: 05/15/2017.

Accepted: 09/27/2017.

Published Online: 04/01/2018

DOI: http://dx.doi.org/10.15728/bbr.2018.15.4.1 
at lower costs and improve their performance. However, it is worth highlighting the alternative view on the subject that supports the fact that these connections will cost the capital, resulting, for example, in the inefficiency of the application of these resources and the informational asymmetries, which, in turn, implies a higher cost of capital and, consequently, a lower performance in relation to firms without connectivity (FACCIO, 2006; CHANEY; FACCIO; PARSLEY, 2011).

Thus, the objective of this study is to investigate the political connections of the Brazilian firms listed on B3, non-financial and without major shareholding of the government, and its influence on market performance in the period from 1998 to 2016. We use the donations for political campaign as a strategy of connection of the companies and proxy of the corruption. From the data extracted from the Economatica ${ }^{\circledR}$ database and the Superior Electoral Court, as well as a regression model data panel with double fixed effect of company and year, we infer the influence of political connections on the cost of capital measured by the cost of third-party capital and the performance of firms; return on assets (ROA); return on equity (ROE); return on invested capital (ROIC); and Market-to-book.

With the results of the statistical tests, we did not obtain empirical evidence to support the assertion that campaign donations improved performance or reduced the cost of capital of connected firms. These results did not support the theoretical and intuitive prediction that campaign donations would positively reflect business, contradicting, in part, most of antecedent studies.

By aligning ourselves with the theoretical body, which studies enterprise-government relations, we show that the present research contributes to the debate related to the political strategies of the organizations, integrating assumptions of the Institutional Theory, extending the period of analysis and identifying the long-term, unimpressive effects of the connection strategy through campaign donations.

This strategy was widely used by companies and politicians in the period of analysis. This relationship can be observed in the data of the Superior Electoral Court (Tribunal Superior Eleitoral - TSE) the 2014 elections, in which approximately $70 \%$ of the elected federal deputies received funds of at least one of the ten companies that made political donations. These ten companies helped elect 360 of the 513 federal deputies.

\section{INSTITUTIONAL THEORYAND POLITICAL CONNECTIONS}

We can understand institutions as any kind of restrictions or limits existing for the interactions between social actors. In other words, institutions are the rule of the game of a society, responsible for the organization of social interactions. From this perspective, the institutional theory, in its economic view, holds that social actors, in particular the government actor, are able to interfere, raising or minimizing the costs of economic activities in general (NORTH; THOMAS, 1972; NORTH, 1990).

Transaction costs can be slowed down when institutions, by definition, establish laws and regulations restricting opportunistic actors; establish effective mechanisms for monitoring and guaranteeing contracts; and at the time they create and maintain legal penalties as a way to punish violators of contractual agreements (HILL, 1995). The absence of coercive and punitive mechanisms is termed by Khanna and Palepu (1997) as institutional voids.

An example of an institutional void in Brazil is the case of the National Petroleum Agency, which is relatively weakened as a result of the executive power being both an administrator and the regulator of state-owned Petrobras. In contrast, there is a strong and autonomous regulatory agency in Norway that has helped develop institutional checks and balances, mitigating the ability of the government to intervene in state-owned companies (MUSACCHIO; LAZZARINI, 2015). 
BBR

15,4

The literature indicates that in developing economies or those in transition, with low institutional development, political connections account for a large part of corporate capitalization (FACCIO, 2006). In this model of capitalization through government subsidy, it is worth highlighting the role of state banks once they operate in all sectors of the economy, entry barriers do not limit the capacity of politicians to transfer resources, providing greater opportunities to channel financial resources, which ends up reflecting a significant increase in loans in electoral years (DINÇ, 2005; RAJAN; ZINGALES, 2003).

We find an example of the aforementioned assertion in the study by Khwaja and Mian (2005). The authors found that between 1996 and 2002, companies with political connections in Pakistan obtained preferential treatment from state-owned banks and had access to financing $45 \%$ more than unconnected companies and had $50 \%$ higher default rates, indicating that the granting of the credit was motivated by the connection and not by technical criteria.

Another highlight in the capitalization of companies linked to politicians, and consequently to financial institutions too, refers to the fact that in order for them to have access to credit, they need collaterals smoother than those that are not connected. This suggests an implicit assurance of government relief in cases of financial hardship and, consequently, greater reliability in long-term financing (KHWAJA; MIAN, 2005).

The literature on this subject predominantly holds that political connections contribute to firms obtaining lower-cost financial resources and improving their performance. However, it is worth mentioning the alternative view that supports the fact that political connections may burden the cost of capital as a result of bad management, lower accounting results and asymmetric information (CHANEY; FACCIO; PARSLEY, 2011), resulting in a higher cost of capital compared to unconnected companies (FACCIO, 2006).

In the Brazilian context, paradoxically, the capital market and regulatory institutions are developing concurrently with politicians offering strong incentives to cultivate particularist relations with the government (INOUE; LAZZARINI; MUSACCHIO, 2013).

We should also point out that the Brazilian government holds the country's two largest commercial banks, the largest development bank and, still has a strong influence on state-owned pension funds. Therefore, the power of offering loans with lower interest rates than those practiced in the market and differentiated conditions makes the political connection very attractive to companies. In addition, the weakening of institutions and low legal protection favor the possibility of returning these favors to politicians in a legal (campaign financing) or illegal way (corruption) (CLAESSENS; FEIJEN; LAEVEN, 2008; XAVIER; BANDEIRA-DE-MELLO; MARCON, 2014).

It is worth mentioning that campaign funding is not necessarily associated with a violation of the law, however there are parallels in the political financing of campaigns with corruption schemes, as evidenced by indictments in several spheres of public power. In the 2014 election campaign, for example, JBS made donations totaling 135 million (BRL), helping to elect 106 of the 523 federal deputies. In the subsequent period, the company received government benefits of around 10 billion (BRL), between exonerations and financing of the National Development Bank (BNDES). This company is the object of investigations of the Federal Police with suspected payment of bribes to obtain loans in the Caixa Econômica Federal (Federal Savings Bank) (GLOBO, 2016).

We recognize that the difficulty of identifying the distortion of the common good in the interests of donors is a challenge for academic research. However, the Brazilian context allows donations to campaigns as the most direct and objective measure of political connection (BANDEIRA-DE-MELLO; MARCON, 2011). Using donations for campaigns is a way to "buy" the political connection. Once the relationship is established, it is clear: the politician "takes" the money and the company gains the favor (SAMUELS, 2001). Although we do 
not easily perceived many of these links with government, certain evidences are reflected in corporate performance (CAMILO; MARCON; BANDEIRA-DE-MELLO, 2012).

In summary, the literature suggests that the connected companies have an incentive to use funding (MYERS E MAJIUF, 1984), since due to this condition, they have easier access to credit and of better quality (CLAESSENS; FEIJEN; LAEVEN, 2008). In addition, they are more likely to be bailed out by the government when they face financial difficulties (FACCIO, 2006). This implicit assurance of distress suggests that there is a tendency for long-term financing (KHWAJA; MIAN, 2005), benefits that ultimately interfere with corporate performance (HILLMAN, 2005). Based on the above, we have developed the following hypotheses:

Companies politically connected, when compared to the other, h1) increase their financial leverage; h2) their return on assets; h3) shareholders' return; h4) their operating profit; h5) their market value; and h6) decrease their cost of capital.

\section{METHODOLOGY}

\subsection{Population, SOURCE AND DATA PROCESSing}

As population, we consider the group of non-financial companies listed on B3, in the period from 1998 to 2016, with active and canceled status, representing data of 19 years of observation and five major electoral debate.

We exclude from the universe of this research the licensed companies or concessionaires of public services for being vetoed by Art. 24 of Electoral Law 9.540/97, which prohibits parties and candidates from receiving contributions directly or indirectly from such companies (BRASIL, 1997).

We obtained the dataset of the analyzed period by means of three secondary sources, comprising the data from the TSE, Economatica ${ }^{\circledR}$ database and from B3. From the TSE database, we capture campaign contributions from companies to parties and candidates in the elections of 1998, 2002, 2006, 2010 and 2014. In the Economatica ${ }^{\circledR}$ database, we collect economic-financial data; and, based on data from B3, we defined the sample firms and analyzed the outliers. We updated the economic data of the companies and donations by the inflation (IPCA) at 2016 values.

The temporal cross-section, from 1998 to 2016, is intended to avoid the period of intense institutional friction prior to 1998 , due to the coexistence of old and new formal and informal institutions and economic agents in the environment, because at this stage the behavior of companies is erratic and defensive and does not necessarily reflect their strategies (HOSKISSON et al., 2000). Moreover, to understand a long and sufficient period to detect whether the political connections through campaign donations gave perennial gains to companies, considering the changes that occurred in the institutional environment, or if there were negative consequences of such changes.

For the data treatment, we used the panel data technique with clustered standard errors at the firm level, with a fixed double effect of firm and time, and with lagged data in one year, in order to minimize related concerns, for example, to heteroscedasticity, endogeneity and characteristics of the non-observable and time-invariant companies omitted in the modeling (Fávero 2013). To estimate the models, we used the Stata/SE ${ }^{\circledR}$ statistical tool.

The general model is given by:

$$
\begin{aligned}
& \text { Performancei,t }=\beta 0+\beta 1 \text { donationi, } t+\beta 2 i \text { Inflationi, } t+\beta 3 G D P i, t+\beta 4 B R i, t+ \\
& \beta 5 \text { SELICi,t }+\beta 6 \text { Exchangei }, t+\beta 7 I E F i, t+\beta 8 \text { TAi }, t+\beta 9 I n i, t+\beta 10 E B I T i, t+\beta 11 R B i, t \\
& +\varepsilon i t
\end{aligned}
$$


BBR

15,4

321

From this formula, the performance $i$, at time $t$, is defined by the metrics ROA, ROE, ROIC, Market-to-book, leveraging and reducing the cost of capital. $\beta 0$ represents intercepts; $\beta 1$ donation represents donations and their derivations, detailed in Tables 2 and 3; from $\beta 2$ to $\beta 11$ we indicate the control variables, detailed in Table 4; and sit represents the error.

\subsection{DEPENDENT VARIABLES}

In relation to the metrics used in this study, given the centrality of the performance theme of companies, as well as the possibility of being assessed from several levels and conceptual bases (VENKATRAMAN; RAMANUJAM, 1986; HAMANN et al., 2013), we tested five dependent variables related to company performance, with the aim of formulating the necessary regressions. The chosen variables are grounded as follows in Table 1.

Table 1. Dependent Variables

\begin{tabular}{|c|c|c|}
\hline Variable & Measurement & Authors \\
\hline Leverage (LVR) & LVR $=($ Total Debt $) /$ Equity & $\begin{array}{l}\text { Procianoy and Schnorrenberger (2004); Lazzarini and } \\
\text { Musacchio (2010); Inoue, Lazzarini and Musacchio (2013) }\end{array}$ \\
\hline Cost of capital (CC) & $\mathrm{CC}=($ Financial expenses $) /($ Total Debt $)$ & $\begin{array}{l}\text { Claessens, Feijen and Laeven (2008); Bandeira-de-Mello and } \\
\text { Marcon (2011); Inoue, Lazzarini and Musacchio (2013); } \\
\text { Lazarine et al. (2015) }\end{array}$ \\
\hline Assets Performance (ROA) & ROA = (Net Profit $) /($ Total Asset $)$ & $\begin{array}{l}\text { Lazzarini et al. (2011); Bandeira-de-Mello et al. (2012); } \\
\text { Camilo, Marcon and Bandeira-de-Mello (2012); Inoue, } \\
\text { Lazzarini and Musacchio (2013) }\end{array}$ \\
\hline $\begin{array}{l}\text { Shareholder investment } \\
\text { performance (ROE) }\end{array}$ & $\begin{array}{c}\mathrm{ROE}=(\text { Lucro líquido }) /(\text { Patrimônio } \\
\text { líquido })\end{array}$ & $\begin{array}{l}\text { Bandeira-de-Mello and Marcon (2005); Li et al. } \\
\text { (2008); Camilo, Marcon e Bandeira-de-Mello (2012); } \\
\text { Okhmatovskiy (2010) }\end{array}$ \\
\hline $\begin{array}{l}\text { Return on invested capital } \\
\text { (ROIC) }\end{array}$ & ROIC = NOPLAT/(Total Capital) & $\begin{array}{l}\text { Ang, Ding and Thong (2013); Menozzi, Urtiaga and } \\
\text { Vannoni, (2011) }\end{array}$ \\
\hline $\begin{array}{l}\text { Market Performance - } \\
\text { Market-to-book (M. Book) }\end{array}$ & M. Book = (Market Value $) /$ Equity & $\begin{array}{l}\text { Fama, (1992); Jiang (2008); Boubakri et al. (2012); } \\
\text { Inoue, Lazzarini and Musacchio (2013) }\end{array}$ \\
\hline
\end{tabular}

Source: Authors' own elaboration (2017).

Note: Leverage represents the capitalization of the company through third-party capital in relation to equity. Total Debt includes short-term and long-term third-party capital. Cost of capital indicates the cost of debt acquired with third parties. Financial expenses indicate the amount spent on interest and bank expenses. ROA (Return on Assets) expresses the profitability of assets. ROE (Return on Equity) indicates the profitability of shareholders. ROIC (Return Over Invested Capital) indicates the return on invested capital. NOPLAT (Net Operating Profit Less Adjusted Taxes) represents operating income before taxes and financial expenses. The invested capital comprises third-party capital and equity. Market-to-book indicates market value of the company in relation to its book value. The values for calculating the metrics were all considered at the end of the period.

We measured the leverage variable by the degree of impairment of equity with third parties, with it being represented by the ratio of short- and long-term debt on the value of equity. In addition to leverage, we use the cost of capital in a complementary way to capture not only access, but also quality in debt collection. We used as proxy of the cost of capital the ratio of financial expenses to total debt. The choice of this metric to the detriment of others, such as the remuneration of third-party capital, is due to the unavailability of data for the whole period, since only from the year 2007 the Law 6.404/76, amended by Law 11.638/2007, obliged all companies listed on B3 to disclose the Statement of Added Value, with this being a limitation of this research.

As a way of measuring performance, we chose to use four variables in a complementary way, with the ROA, ROE, ROIC and market-to-book. ROA captures company performance, taking into account the profit and assets of the company used to achieve such a result; ROE captures the return of the shareholder's investments, considering the net income and the investments of the shareholders; ROIC captures the return on invested global capital, considering net income and the investment of shareholders and third parties; whereas 
market-to-book captures expectations of future profits from investors and is measured by the ratio between the market value of the shares and their book value of equity. Since the choice of more advantageous financing sources produces better results for the company, such as maximizing profits to owners, it becomes more attractive to the market.

\subsection{INDEPENDENT VARIABLES}

Given the purpose of the research, we consider only the donations directly passed on to the candidates, since donations made to committees and parties cannot be linked to individual candidates. The independent variable is based as shown in Table 2.

Thus, the variable donation was derived in 17 other variables in order to capture more accentuated relationships with certain roles. In Table 3, we explain the segregation.

\subsection{Control variableS}

The macroeconomic variables and the institutional environment are due to the fact that uncertainty and political interference in the environment negatively affect the economy and, consequently, the companies, reducing the growth rates (HENISZ, 2000). However, for companies, such a relationship has its effect mitigated when they are politically connected, the success of economic activities through political connections (KHANNA; PALEPU, 1997). The control variables are based as explained in Table 4.

Table 2. Independent variable

\begin{tabular}{|lll|}
\hline Variable & Meaning and measurement & Authors \\
\hline Donation & $\begin{array}{l}\text { Monetary value of the contribution that the company } \\
\text { registered in the TSE in the major debates from 1998 to } \\
2014\end{array}$ & $\begin{array}{l}\text { Claessens, Feijen and Laeven (2008); Bandeira-de-Mello and } \\
\text { Marcon (2011); Camilo, Marcon and Bandeira-de-Mello } \\
\text { (2012) }\end{array}$ \\
\hline
\end{tabular}

Source: Authors' own elaboration (2017).

Table 3. Segregation of the donation variable

\begin{tabular}{|lc|}
\hline Variable & Code \\
\hline Total amount donated in campaign & Total Don. \\
Amount donated to winner candidate & Don. Winner \\
Amount donated to losing candidate & Don. Loosing \\
Amount donated to candidate for Presidential & Don. Presid. \\
Amount donated to the winner candidate President & Don. Winner Presid. \\
Amount donated to the losing candidate President & Don. Loosing Presid. \\
Amount donated to candidate for Governor & Don. Gover. \\
Amount donated to the winner Governor candidate & Don. Winner Gover. \\
Amount donated to the losing Governor candidate & Don. Loosing Gover. \\
Amount donated to candidate for Senator & Don. Senator \\
Amount donated to the winner Senator candidate & Don. Winner Senator \\
Amount donated to the losing Senator candidate & Don. Loosing Senator \\
Amount donated to candidate for Federal Deputy & Don. Fed. Dep. \\
Amount donated to the winner candidate for Federal Deputy & Don. Winner Fed. Dep. \\
Amount donated to the loosing candidate for Federal Deputy & Don. Loosing Fed. Dep. \\
Amount donated to candidate for State/District Deputy & Don. Sta. Dep. \\
Amount donated to winner candidate for State/District Deputy & Don. Winner Sta. Dep. \\
Amount donated to loosing candidate for State/District Deputy & Don. Loosing Sta. Dep. \\
\hline
\end{tabular}

Source: Authors' own elaboration (2017). 
BBR

15,4

323

Table 4. Control Variables

\begin{tabular}{|c|c|c|}
\hline Variable & Meaning and Measurement & Authors \\
\hline Economic Sector & $\begin{array}{l}\text { Indicates the sector of the economy in which the company } \\
\text { is located, considering the sectors of Economatica }{ }^{\circledR} \text {. }\end{array}$ & $\begin{array}{l}\text { Camilo, Marcon and Bandeira-de-Mello (2012); } \\
\text { Claessens, Feijen and Laeven (2008) }\end{array}$ \\
\hline Market reforms & $\begin{array}{l}\text { Expresses the level of implementation of the Brazilian } \\
\text { market reforms through the index of economic freedom } \\
\text { (IEF) of the Heritage Foundation. }\end{array}$ & $\begin{array}{l}\text { Cuervo-Cazurra and Dau (2009); Xavier, } \\
\text { Bandeira-de-Mello and Marcon (2014) }\end{array}$ \\
\hline Inflation & $\begin{array}{l}\text { Expresses the annual percentage change in prices through } \\
\text { the Broad Consumer Price Index (IPCA) }\end{array}$ & $\begin{array}{l}\text { Fialho (1997); Nunes, Da Costa Jr. and Meurer (2005); } \\
\text { Dinç (2005) }\end{array}$ \\
\hline $\begin{array}{l}\text { Gross Domestic } \\
\text { Product (GDP) }\end{array}$ & $\begin{array}{l}\text { Expresses the value of the goods and services produced in } \\
\text { the year through the LN nominal value. }\end{array}$ & $\begin{array}{l}\text { Nunes, Da Costa Jr. and Meurer (2005); Dinç (2005); } \\
\text { Boubakri et al. (2012); Xavier, Bandeira-de-Mello and } \\
\text { Marcon (2014) }\end{array}$ \\
\hline Brazil Risk (BR) & $\begin{array}{l}\text { Expresses the degree of risk and uncertainty that the } \\
\text { country presents to the foreign investor through the } \\
\text { Emerging Markets Index (EMBI+Br) of the JP Morgan } \\
\text { Bank. }\end{array}$ & $\begin{array}{l}\text { Fialho (1997); Garcia and Didier (2003); Nonnenberg } \\
\text { and Mendonça (2005) }\end{array}$ \\
\hline Selic Rate & $\begin{array}{l}\text { Expresses the basic interest rate in the market through its } \\
\text { percentage. }\end{array}$ & $\begin{array}{l}\text { Garcia and Didier (2003); Nunes, Da Costa Jr. and } \\
\text { Meurer (2005); Nonnenberg and Mendonça (2005); } \\
\text { Costa, Bandeira-de-Mello and Marcon (2013) }\end{array}$ \\
\hline Exchange & $\begin{array}{l}\text { Expresses the value of the foreign currency through the } \\
\text { value in reais (BRL) from dollar (USD). }\end{array}$ & $\begin{array}{l}\text { Fialho (1997); Garibaldi et al. (2001); Dinç (2005); } \\
\text { Nonnenberg and Mendonça (2005) }\end{array}$ \\
\hline Total asset (TA) & $\begin{array}{l}\text { Expresses the size of the company through the } \mathrm{LN} \text { of the } \\
\text { total assets. }\end{array}$ & $\begin{array}{l}\text { Fan } e t \text { al. (2007); Claessens, Feijen and Laeven (2008); } \\
\text { Inoue, Lazzarini and Musacchio (2013) }\end{array}$ \\
\hline Indebtedness (In) & $\begin{array}{l}\text { Expresses the degree of commitment of the asset to debt. } \\
\text { In = (Total liability)/(Total asset) }\end{array}$ & $\begin{array}{l}\text { Myers and Majiuf, (1984); Claessens, Feijen and Laeven } \\
\text { (2008); Camilo, Marcon and Bandeira-de-Mello } \\
\text { (2012); Boubakri et al. (2012) }\end{array}$ \\
\hline EBIT & $\begin{array}{l}\text { Expresses operating profit before interest and taxes } \\
\text { through LN EBIT. }\end{array}$ & Claessens, Feijen and Laeven (2008) \\
\hline Gross revenue & $\begin{array}{l}\text { Represents the size of the company through the LN gross } \\
\text { revenue. }\end{array}$ & $\begin{array}{l}\text { Titman and Wessels (1988); Claessens, Feijen and } \\
\text { Laeven (2008); Boubakri et al. (2012) }\end{array}$ \\
\hline
\end{tabular}

Source: Authors' own elaboration (2017).

Note: The sectors of the economy follow the sectorial classification of Economatica ${ }^{\circledR}$ and are divided into: Agribusiness and Fisheries, Food \& Beverage, Trade, Construction, Electrical Appliances Sector, Electric Power, Finance and Insurance, Funds, Industrial Machinery, Mining, Non-Metallic Minerals, Others, Paper and Pulp, Gas Oil, Chemical, Steel and Metallurgical, Software and Data, Telecommunications, Textiles, Transportation and Services, Vehicles and Parts. The index of economic freedom (IEC) it varies from 0 to 100 and the closer to 100 the greater the degree of implementation. Inflation (\%) considered was the Broad Consumer Price Index (IPCA) measured by the Brazilian Institute of Geography and Statistics (IBGE). Brazil Risk, (EMBI+) of the JP Morgan Bank, was considered in Base points on the last day of each year. The exchange rate considered was the value of the Dollar in reais on the last day of each year. The EBIT (Earnings Before Interest and Taxes) indicates the profit before interest and taxes through the LN of the EBIT.

\section{RESULTS}

Concerning the political connections through the campaign donations, we observed an increasing use of this strategy as evidenced in Graph 1, in which the amount given to candidates by the companies are presented. Such a result is understandable, given the inherent cost of Brazilian political campaigns and companies' interest in minimizing environmental uncertainties.

In Graph 2, we can see that, in general, companies in the sample made larger donations to candidates for executive positions, approximately $70 \%$ of the donations from the review period were donated to the candidates for president and governor. This may indicate interest with more centrality for environments with more intensive political powers, influential and, consequently, with greater possibilities of returning favors.

Table 5, next, presents the descriptive statistics of the variables. In it, we observe that on average companies donate more to winner candidates, except for donations to governors. In general, we emphasize that companies support a wide range of candidates, given the representative amount donated to losing candidates. This suggests that companies try 


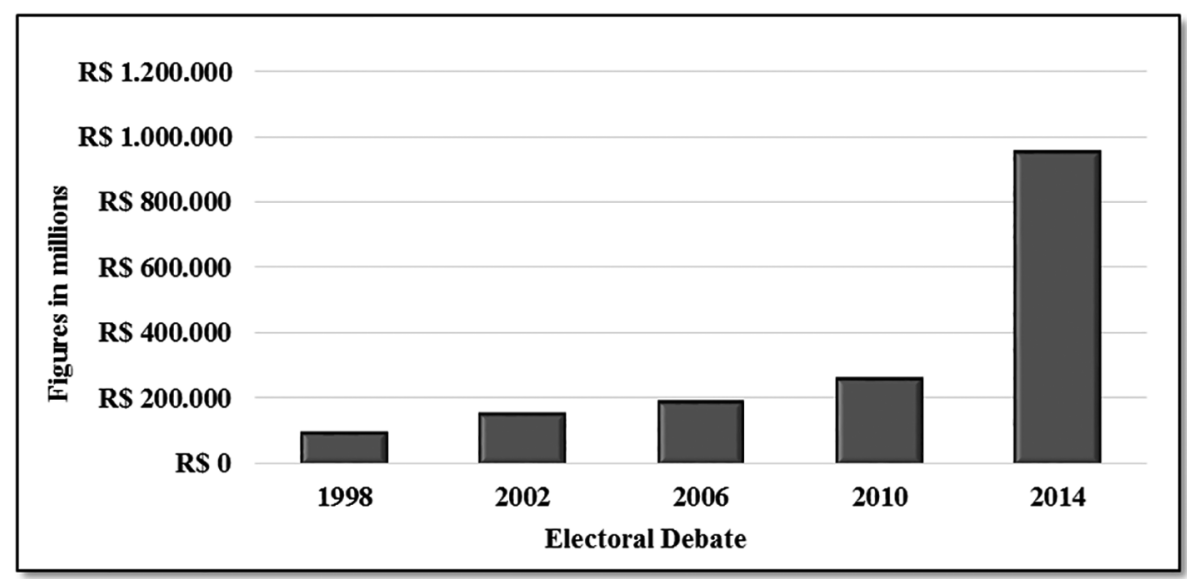

Source: Research Data (2017).

Graph 1. Values donated to candidates by sample companies

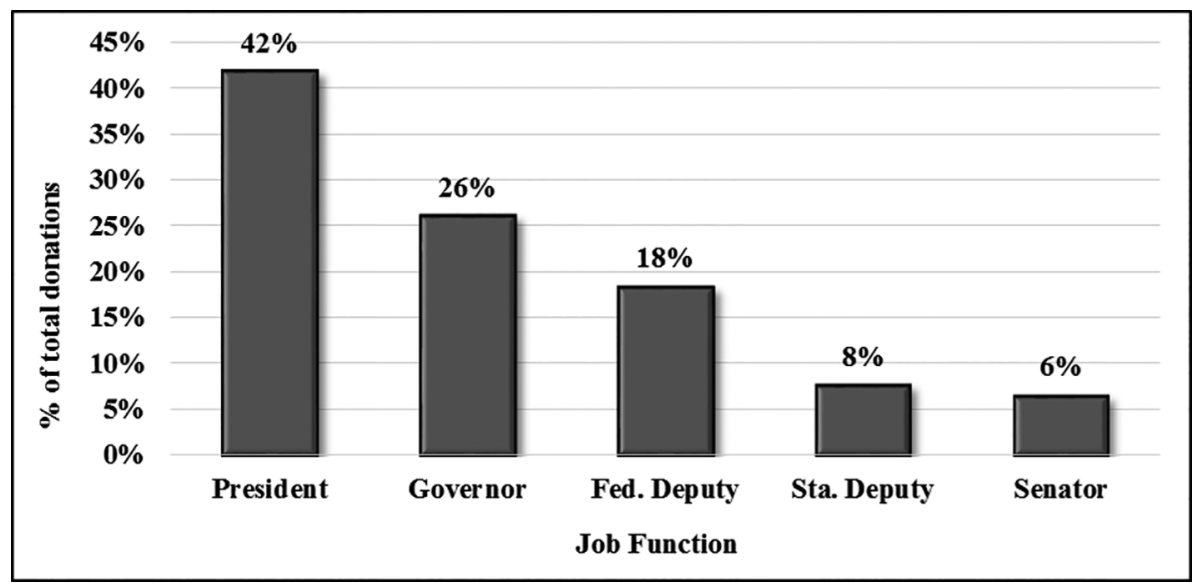

Source: Research Data (2017).

Graph 2. Percentage of amounts donated per position in the period from 1998 to 2014

to minimize risk by also donating to candidates with potential to succeed in the debate, regardless of their party affiliation.

The results of the estimation of the models are presented in Table 6 . In it, we focus on total donations per role. The results of the other derivations, such as the donations to winner and losing candidates, are reported later along with the robustness tests. In general terms, with the exception of the cost of capital, the model was significant (Prob $>\mathrm{F}$ at 1\%). However, the explanatory power of the model $\left(\mathrm{R}^{2}\right)$ points out that the donations are not able to explain part of the variability of the dependent variables.

The established assumptions foresee that politically connected companies, when compared to other, h1) increase their financial leverage, h2) their return on assets (ROA), h3) their return on equity (ROE), h4) their return on invested capital (ROIC), h5) their market value (Market-to-book), and h6) decrease their cost of capital. In general, the test results of the variables were not statistically significant, with the results largely inconclusive on the influence of donations on the cost of capital and on the performance of the sample firms.

The significant results in the variables of interest were presented in the cases of donations to the president in leverage (5\%) and in $\operatorname{ROE}(10 \%)$. Donations to candidates for Federal Deputy and State Deputy were also significant in ROIC, in both cases at 5\%. However, in all cases the coefficients were very close to zero. 
BBR

15,4

325

Table 5. Descriptive statistics of variables

\begin{tabular}{|c|c|c|c|c|c|c|c|}
\hline & Mean & SD & Min & P25 & $\mathrm{P} 50$ & P75 & Max \\
\hline Leverage & 65.4507 & 1620.679 & -10253.33 & 0.0763 & 0.4130 & 1.0914 & 75718.73 \\
\hline Cost of capital & 4.9944 & 84.6605 & -1485.75 & 0.1272 & 0.2071 & 0.4067 & 3820.444 \\
\hline ROA & -19.3314 & 1169.364 & -103642 & -0.0406 & 0.0205 & 0.0799 & 31510 \\
\hline ROE & 1.2415 & 138.4884 & -4917.556 & -0.0082 & 0.0873 & 0.2068 & 10443 \\
\hline ROIC & $1.5 e+12$ & $1.09 \mathrm{e}+14$ & -103642 & -0.0482 & 0.0212 & 0.0897 & $7.9 \mathrm{e}+16$ \\
\hline Market-to-book & 1.7406 & 14.3014 & -853.2563 & 0.4523 & 0.9974 & 1.9753 & 250.6581 \\
\hline Total Don. & 5.2419 & 2.8673 & -8.6595 & 3.6169 & 5.6130 & 7.0675 & 12.7026 \\
\hline Don. Winner & 5.3568 & 2.3545 & -7.2732 & 3.8524 & 5.4604 & 6.8910 & 12.0372 \\
\hline Don. Loosing & 4.8497 & 2.8116 & -8.6592 & 3.444 & 5.0527 & 6.6557 & 11.9809 \\
\hline Don. Presid. & 7.0979 & 1.7112 & 3.8524 & 5.9289 & 6.8736 & 7.9581 & 12.4465 \\
\hline Don. Winner Presid. & 6.7774 & 1.6212 & 3.1592 & 5.5565 & 6.6436 & 7.7113 & 11.7534 \\
\hline Don. Loosing Presid. & 6.7304 & 1.9237 & 3.1592 & 5.1856 & 6.4035 & 7.7113 & 11.7534 \\
\hline Don. Gover. & 5.9648 & 2.0439 & -4.2936 & 5.0032 & 6.0936 & 7.2726 & 10.8137 \\
\hline Don. Winner Gover. & 5.6438 & 1.6662 & 0.7953 & 4.5876 & 5.7369 & 6.6814 & 10.0721 \\
\hline Don. Loosing Gover. & 5.7338 & 2.0346 & -4.2936 & 4.7687 & 5.9195 & 7.0701 & 10.3076 \\
\hline Don. Senator & 5.2552 & 2.0209 & -3.7596 & 4.3101 & 5.4397 & 6.4301 & 9.0591 \\
\hline Don. Winner Senator & 5.1584 & 1.9841 & -4.4527 & 4.2369 & 5.3448 & 6.4035 & 87.390 \\
\hline Don. Loosing Senator & 4.7874 & 2.0338 & -4.4527 & 4.2578 & 5.0283 & 5.8362 & 77.644 \\
\hline Don. Fed. Dep. & 4.6470 & 2.6065 & -9.9631 & 3.3938 & 4.8303 & 6.2070 & 95.618 \\
\hline Don. Winner Fed. Dep. & 4.8661 & 2.0999 & -1.06563 & 3.5663 & 4.9072 & 6.1988 & 93.147 \\
\hline Don. Loosing Fed. Dep. & 4.1772 & 2.6432 & -1.06563 & 3.2101 & 4.6322 & 5.7979 & 81.400 \\
\hline Don. Sta. Dep. & 4.1091 & 2.7062 & -9.2191 & 3.2080 & 4.4924 & 5.7242 & 88.583 \\
\hline Don. Winner Sta. Dep. & 4.4056 & 2.2129 & -9.2191 & 3.2802 & 4.6188 & 5.7446 & 83.813 \\
\hline Don. Loosing Sta. Dep. & 3.6553 & 2.5773 & -8.6595 & 2.8534 & 4.0379 & 5.1224 & 83.532 \\
\hline IEF & 58.3748 & 3.1720 & 52.3 & 56.2 & 57.7 & 61.5 & 63.4 \\
\hline Inflation & 6.5615 & 2.4741 & 1.65 & 5.68 & 5.97 & 7.67 & 12.53 \\
\hline GDP & 14.0427 & 0.2604 & 13.5970 & 13.8051 & 14.0370 & 14.3053 & 14.3904 \\
\hline Brazil Risk & 473 & 357.3383 & 142 & 208 & 328 & 636 & 1446 \\
\hline SELIC & 14.9605 & 5.3989 & 7.14 & 10.9 & 13.66 & 18 & 29.21 \\
\hline Exchange & 2.3370 & 0.6655 & 1.21 & 1.79 & 2.3204 & 2.6536 & 3.9 \\
\hline Total Asset & 13.1015 & 3.1479 & -6.3356 & 11.8432 & 13.6420 & 15.0311 & 21.2399 \\
\hline Indebtedness & 13298.5 & 340807 & -1968480 & 13.0089 & 71.3205 & 186.4037 & $1.88 \mathrm{e}+7$ \\
\hline EBIT & 11.4068 & 2.3199 & -0.3243 & 10.0688 & 11.6931 & 12.9763 & 18.2937 \\
\hline Gross Revenue & 12.3037 & 2.8504 & -1.9988 & 10.8022 & 12.8686 & 14.3594 & 19.5758 \\
\hline
\end{tabular}

Source: Research Data (2017).

Note: The table presents the descriptive statistics of the sample, of which 886 companies are listed on the stock exchange, with active and canceled status, in the period from 1998 to 2016. Mean stands for mean. SD stands for standard deviation. Min stands for minimum value. P25, P50 and P75 are the percentiles 25, 50 and 75 respectively. Max stands for maximum value. The variables that indicate values are updated by inflation (IPCA) to 2016 reais (BRL). The dependent variables are represented in the first block of the table, respectively: leverage (LVR), cost of capital (CC), performance of assets (ROA), shareholder investment performance (ROE), return on invested capital (ROIC) and market performance (M. Book). The independent variables are the donations and are indicated in the second block of the table through the LN of the monetary value of the contribution. The control variables are indicated in the third block. The control variables related to the macro environment are: a) The index of economic freedom (IEF), which indicates the level of implementation of market reforms through the Heritage Foundation index, ranging from 0 to 100 and the closer to 100 the greater the degree of implementation; b) Inflation, which indicates the change in prices (\%) through the Broad Consumer Price Index (IPCA); c) The Gross Domestic Product (GDP), which indicates the value of goods and services produced in the year through the LN nominal value; d) Brazil Risk, which indicates the degree of risk and uncertainty presented by the country to the foreign investor through the Emerging Markets Index (EMBI+) of the JP Morgan Bank, considered in Base points of the last day of each year; e) The Selic rate expresses the basic interest rate (\%) in the market; $x$ The exchange rate indicates the value of the foreign currency through the value in reais (BRL) of the dollar (USD). The control variables at company level are: g) The total asset, which represents the size of the company through the LN of the total assets; h) The degree of indebtedness, which represents the degree of the asset committed to debt through the ratio of total liabilities and total assets; i) The EBIT (Earnings Before Interest and Taxes), which indicates the profit before interest and taxes through the LN of EBIT; and j) Gross revenue, which represents the size of the company through the LN of gross revenue. 
Table 6. Regression results

\begin{tabular}{|c|c|c|c|c|c|c|}
\hline & Lev. & ROA & ROE & ROIC & M. Book & C. Cap. \\
\hline \multirow{2}{*}{ Donor President } & $0.027^{* *}$ & 0.866 & $0.072 *$ & 0.278 & 0.269 & 0.666 \\
\hline & $(-9.43 e-06)$ & $(7.73 e-08)$ & $(5.14 \mathrm{e}-06)$ & $(.0000126)$ & $(.0000125)$ & $(-.0000263)$ \\
\hline \multirow{2}{*}{ Donor Governor } & 0.108 & 0.516 & 0.117 & 0.903 & 0.391 & 0.309 \\
\hline & $(.000074)$ & $(2.32 \mathrm{e}-06)$ & $(-.0000347)$ & $(-1.07 e-06)$ & $(-.0000727)$ & $(.0006187)$ \\
\hline \multirow{2}{*}{ Donor Senator } & 0.683 & 0.433 & 0.873 & 0.391 & 0.905 & 0.315 \\
\hline & $(.0000851)$ & $(-.0000227)$ & $(-.000017)$ & $(.0000248)$ & $(-.000057)$ & $(-.0021753)$ \\
\hline \multirow{2}{*}{ Donor Federal Dep. } & 0.266 & 0.964 & 0.285 & $0.042^{* *}$ & 0.871 & 0.556 \\
\hline & $(-.0002015)$ & $(-7.41 e-07)$ & $(.0000814)$ & $(-.0000575)$ & $(-.0000535)$ & $(.0006342)$ \\
\hline \multirow{2}{*}{ Donor State Dep. } & 0.511 & 0.649 & 0.838 & $0.043^{* *}$ & 0.326 & 0.186 \\
\hline & $(.0002517)$ & $(-.0000156)$ & $(.0000216)$ & $(.0000612)$ & $(.0004064)$ & $(-.0032305)$ \\
\hline \multirow{2}{*}{ Market reforms (ILE) } & $0.052^{* *}$ & 0.932 & 0.288 & 0.311 & 0.187 & 0.658 \\
\hline & $(-1.520609)$ & $(.0027381)$ & $(.3681389)$ & $(.1103361)$ & $(-2.167201)$ & $(8.184121)$ \\
\hline \multirow{2}{*}{ Inflation } & $0.078^{*}$ & 0.885 & 0.318 & 0.317 & 0.234 & 0.707 \\
\hline & $(2.418904)$ & $(-.0085702)$ & ( -.6091953) & $(-.1932034)$ & $(3.544786)$ & $(-12.19866)$ \\
\hline \multirow{2}{*}{ GDP } & $0.091^{*}$ & 0.829 & 0.314 & 0.306 & 0.215 & 0.682 \\
\hline & $(-20.09967)$ & $(-.1070538)$ & $(5.225467)$ & ( 1.680481$)$ & $(-31.84907)$ & $(117.4516)$ \\
\hline \multirow{2}{*}{ Brazil Risk } & $0.094^{*}$ & 0.973 & 0.349 & 0.356 & 0.195 & 0.721 \\
\hline & $(-.0257564)$ & $(.0000222)$ & $(.0061555)$ & $(.001939)$ & $(-.0421866)$ & $(.1261906)$ \\
\hline \multirow{2}{*}{ Total Assets } & 0.582 & 0.456 & 0.144 & 0.458 & 0.348 & 0.184 \\
\hline & $(-.1240882)$ & (.0789977) & $(-.106942)$ & $(.0873345)$ & $(-.4604565)$ & (1.66193) \\
\hline \multirow{2}{*}{ Indebtedness } & $0.000^{* * *}$ & 0.423 & 0.127 & 0.589 & $0.000^{* * *}$ & 0.513 \\
\hline & $(.0090151)$ & $(-2.52 \mathrm{e}-06)$ & $(-.0006552)$ & $(-3.30 \mathrm{e}-06)$ & $(.0040579)$ & $(-6.26 e-07)$ \\
\hline \multirow{2}{*}{ EBIT } & 0.920 & $0.001^{* * *}$ & 0.297 & $0.005^{* * *}$ & 0.282 & 0.162 \\
\hline & $(.0274187)$ & $(.0364851)$ & $(.0647029)$ & $(.0278737)$ & $(.3436906)$ & $(-1.448378)$ \\
\hline \multirow{2}{*}{ Gross Revenue } & 0.851 & 0.797 & 0.421 & 0.296 & 0.120 & 0.795 \\
\hline & (.0137009) & $(.0026489)$ & $(.0231894)$ & $(-.0115624)$ & $(.1383697)$ & $(-.1092865)$ \\
\hline FE for year & Yes & Yes & Yes & Yes & Yes & Yes \\
\hline FE for company & Yes & Yes & Yes & Yes & Yes & Yes \\
\hline No of Obs. & 1107 & 1104 & 1104 & 674 & 704 & 1091 \\
\hline Prob $>$ F & 0.0000 & 0.0000 & 0.0001 & 0.0000 & 0.0000 & 0.7585 \\
\hline $\mathrm{R}^{2}$ total & 0.0000 & 0.0390 & 0.2002 & 0.0437 & 0.2469 & 0.0009 \\
\hline
\end{tabular}

Source: Research Data (2017)

Note: The table contains the estimates for the OLS, $\mathrm{N}=16834,886$ listed companies, with active and canceled status, in the period from 1998 to 2016. P-values are indicated in the first line. The coefficients are indicated in the second row in parentheses. ${ }^{*},{ }^{* *}$ and ${ }^{* * *}$ indicate statistical significance $10 \%, 5 \%$ and $1 \%$, respectively. Regressions include the fixed effects for year and company. Clustered standard errors per company. The variables that indicate values are updated by inflation (IPCA) to 2016 reais (BRL). Data is out of date by one year. The dependent variables are leverage (LVR), cost of capital (CC), performance of assets (ROA), shareholder investment performance (ROE), return on invested capital (ROIC) and market performance (M. Book). The independent variables are the donations indicated in thousands of reais (BRL) and in absolute values. The control variables related to the macro environment are: a) The index of economic freedom (IEF), which indicates the level of implementation of market reforms through the Heritage Foundation index, ranging from 0 to 100 and the closer to 100 the greater the degree of implementation; b) Inflation, which indicates the change in prices (\%) through the Broad Consumer Price Index (IPCA); c) The Gross Domestic Product (GDP), which indicates the value of goods and services produced in the year through the LN nominal value; d) Brazil Risk, which indicates the degree of risk and uncertainty presented by the country to the foreign investor through the Emerging Markets Index (EMBI+) of the JP Morgan Bank, considered in Base points of the last day of each year; e) The Selic rate and the exchange rate, expressing respectively, the basic interest rate (\%) in the market and the value of the foreign currency through the value in reais (BRL) of the dollar (USD), were drawn from the model because they represent a linear combination of the other control variables. The control variables at company level are: $\mathrm{f}$ ) The total asset, which represents the size of the company through the LN of the total assets; g) The degree of indebtedness, which represents the degree of the asset committed to debt through the ratio of total liabilities and total assets; h) The EBIT (Earnings Before Interest and Taxes), which indicates the profit before interest and taxes through the LN of EBIT; and i) Gross revenue, which represents the size of the company through the $\mathrm{LN}$ of gross revenue. 
BBR

15,4

This finding is partly aligned with the results of the study by Lazzarini and Musacchio (2010). Neither these authors find a relation between the leverage and connection with the government, through this as a minority shareholder, considering the period of 1995 to 2003.

The results related to ROA corroborate the findings by Bandeira-de-Mello et al. (2012). These scholars also used campaign donations in an attempt to find political influences on the return on corporate assets, in the period from 2003 to 2009, indicating that the universe was sensitive, but with non-significant results. The results of the research by Lazzarini et al. (2011), in the same way, signal in this sense, i.e., the researchers point out that political connections, through campaign donations, influence other aspects but have no effect on the ROA of the companies.

In contrast, Lazzarini and Musacchio (2010), Inoue, Lazzarini and Musacchio (2013) found a positive relation on the ROA of the companies when the political connection is established through the minority participation. Therefore, the government promotes longterm investments and, on the other hand, companies are less susceptible to governmental interference and expropriation of minorities.

Results related to ROE are in line with those by Bandeira-de-Mello and Marcon (2005), since similarly, the authors found no relationship between donations and shareholder returns. In contrast, Bandeira-de-Mello et al. (2012), when analyzing the period from 2003 to 2006 , found a positive and significant relationship between the variables, driven mainly by the reduction of debt costs.

The findings related to ROIC are aligned with Menozzi, Urtiaga, Vannoni, (2011) and Ang, Ding, Thong, (2013). These authors found no positive relationship between the political connection, through politically connected counselors, and the return on capital invested in Italy and Singapore respectively. To the extent that it was possible to research, we did not find studies on the Brazilian context and that used this variable.

The findings related to the Market-to-book do not corroborate the theoretical prediction that the political connection through campaign donations increases the value of companies. In research by Camilo, Marcon and Bandeira-de-Mello (2012) and Inoue, Lazzarini and Musacchio (2013), this relationship is found in a significant way, but it should be noted that the periods of analysis in these studies were from 1998 to 2009 and from 1995 to 2009 .

In the case of the cost of capital, its reduction was not confirmed. This result corroborates, in some respects, findings by Claessens, Feijen and Laeven (2008), because the variable is sensitive in some aspects in the reduction of the cost of capital; however it does not present statistical significance.

We submit our results to several additional robustness tests. By rotating the model separately for the financial sector, we did not obtain a sufficient number of observations. However, its inclusion or not in the model did not produce qualitative changes in the results, presenting in the same way without statistical significance. In addition, we tested the model with contemporary data, lags of 1, 2 and 3 years, the fixed effect and clusterstandard errors by sector and the use of robust standard errors. In addition, we evaluate the variations of positions and results of the debate (winner/loosing), the variables of donations with the factorial analysis and variable Dummy of donor and non-donor. The results of the robustness tests corroborated the results of the presented model, in some cases demonstrating sensitivity to the donations, especially in the Market-to-book, but without statistical relevance.

A possible explanation for these results is due to the fact that in periods of political instability and corruption scandals, the connected/involved companies end up incurring substantial losses, as in the case of JBS, which, in one day, lost more than $30 \%$ of its market value, which represents a loss of approximately 7.4 billion (BRL), and will still have to pay the fine 10.3 billion (BRL) related to the leniency agreement with the Public Federal Ministry. 
In general terms, the results of the present study are in part related to studies by Bandeirade-Mello and Marcon (2005), Claessens, Feijen and Laeven (2008), Bandeira-de-Mello et al. (2012), Inoue, Lazzarini and Musacchio (2013), Lazzarini et al. (2011). However, it points, partially, in another direction, of the findings of these same studies, specifically those of positive and significant relationships between the variables. Such differences are due to the use of additional explanatory variables, such as government as a minority shareholder, political background, interlocking and different periods of analysis.

\section{FINAL CONSIDERATIONS}

Starting from the theoretical assumption that the strategy of political connection in the Brazilian context, characterized by its low institutional development, would bring benefits to companies, we investigated the influence of these connections on the cost of capital and the performance of Brazilian companies listed on B3 under the theoretical perspective of the Institutional Theory, integrating the fields of strategy and finance.

By aligning ourselves with the theoretical body that studies business-government relations, we contribute to the debate related to the political strategies of organizations, integrating assumptions of the Institutional Theory, extending the period of analysis and identifying the inexpressive effects in the long term, of the connection strategy through campaign donations.

In summary, we did not obtain empirical evidences that allow affirming that the effect of the donations in the cost of capital and in the performance of the connected companies is different from zero. These findings did not support the theoretical and intuitive prediction that the political connection through donations reduces the cost of capital and improves corporate performance. We also note that studies on the influence of political connections on the performance of Brazilian companies present ambiguous results, i.e., although they robustly show the benefits of this relationship, they end up documenting losses.

Another point concerns the limitations we found in this research, since we use financial expenses as a proxy for the cost of capital, given the limitation of bank debt data in a segregated way for the entire review period and campaign donations as a proxy for corruption.

This research scope may be better represented in future studies, in relation to theoretical integration; or in relation to the method or amplitude of variables, such as the inclusion of connections through the government as a minority shareholder; political background and interlocking, intending to improve the explanatory power of the model; or whether higher-risk companies are more likely to ally themselves politically.

\section{REFERENCES}

ANG, J. S.; DING, D. K.; THONG, T. Y. Political connection and firm value. Asian Development Review, v. 30, n. 2, p. 131-166, 2013.

BANDEIRA-DE-MELLO, R.; MARCON, R. Unpacking firm effects: modeling political alliances in variance decomposition of firm performance in turbulent environments. Brasilian Administration Review - BAR, v. 2, n. 1, p. 21-37, 2005.

BANDEIRA-DE-MELLO, R.; MARCON, R. The value of business group affiliation for political connections: preferential lending in Brazil. In: V ENCONTRO DE ESTUDOS EM ESTRATÉGIA - 3ES, Porto Alegre - RS, 5, Anais... Porto Alegre: ANPAD, 2011.

BANDEIRA-DE-MELLO, R.; MARCON, R.; ZAMBALDI, F.; GOLDSZMIDT, R. G. B. Firm performance effects of nurturing political connections through campaign contributions. African Journal of Business Management, v. 6, n. 9, p. 3327-3332, 2012.

BOUBAKRI, N.; GUEDHAMI, O.; MISHRA, D.; SAFFAR, W. Political connections and the cost of equity capital. Journal of Corporate Finance, v. 18, n. 3, p. 541-559, 2012. 
BBR

15,4

BRASIL. Lei $n^{\circ}$ 9. 504, de 30 de setembro de 1997. Estabelece normas para as eleições. Brasília: Diário Oficial da União, 1997.

CAMILO, S. P. O.; MARCON, R.; BANDEIRA-DE-MELLO, R. Conexões políticas e desempenho: um estudo das firmas listadas na BM\&FBOVESPA. Revista de Administração Contemporânea - RAC, v. 16, n. 6, p. 784-805, 2012.

CHANEY, P. K.; FACCIO, M.; PARSLEY, D. The quality of accounting information in politically connected firms. Journal of Accounting and Economics, v. 51, n. 1, p. 58-76, 2011.

CLAESSENS, S.; FEIJEN, E.; LAEVEN, L. Political connections and preferential access to finance: The role of campaign contributions. Journal of Financial Economics, v. 88, n. 3, p. 554-580, 2008.

CUERVO-CAZURRA, A.; DAU, L. A. Promarket reforms and firm profitability indeveloping countries. The Academy of Management Journal, v. 52, n. 6, p. 1348-1368, 2009.

COSTA, M.; MELLO, R. B.; MARCON, R. Influência da conexão política na diversificação dos grupos empresariais brasileiros. Revista de Administração de Empresas - RAE, v. 53, n. 4, p. 376-387, 2013.

DINÇ, I. S. Politicians and banks: Political influences on government-owned banks in emerging markets. Journal of Financial Economics, v. 77, n. 2, p. 453-479, 2005.

FACCIO, M. Politically connected firms. The American Economic Review, v. 96, n. 1, p. 369-386, 2006.

FAMA, E. F.; FRENCH, K. R. The cross-section of expected stock returns. The Journal of Finance, v. 47, n. 2, p. 427-465, 1992.

FAN, J. H.; WONG, T. J.; ZHANG, T. Politically connected CEOs, corporategovernance, andPost-IPI performance of China's newly partially privatized firms. Journal of Financial Economics, v. 84, n. 5, p. 330-357, 2007.

FIALHO, T. M. M. Testando a evidência de ciclos políticos no Brasil. Revista Brasileira de Economia, v. 51, n. 3, p. 379-390, 1997.

GARCIA, M. G. P.; DIDIER, T. Taxa de juros, risco cambial e risco Brasil. Pesquisa e planejamento econômico, v. 33, n. 2, p. 253-297, 2003.

GARIBALDI, P.; MORA, N.; SAHAY, R.; ZETTELMEYER, J. What moves capital to transition economies. IMF Staff Papers, v. 48, Special Issue, p. 109-145, 2001.

GLOBO. PF prende doleiro ligado a Cunha e mira empresa do grupo dono da JBS. São Paulo, 01 jul. 2016. Disponível em: < http://g1.globo.com/politica/operacao-lava-jato/noticia/2016/07/operacao-temmandado-de-prisao-contra-doleiro-ligado-cunha.html >. Acesso em: 28 fev. 2017.

HAMANN, P. M; SCHIEMANN, F.; BELLORA, L.; GUENTHER, T. W. Exploring the dimensions of organizational performance: A construct validity study. Organizational Research Methods, v. 16, n. 1, p. 67-87, 2013.

HENISZ, W. J. The Institutional environment for economic growth. Economics andPolitics, v. 12, n. 1, p. $1-31,2000$.

HILL, C. W. National institutional structures, transaction cost economizing andcompetitive advantage: the case of Japan. Organization Science, v. 6, n. 1, p. 119-131, 1995.

HILLMAN, A. J. Politicans on the board of directors: do connections affect the bottom line? Journal of Management, v. 3, n. 3, p. 464-481, 2005.

HILLMAN, A. J.; HITT, M. A. Corporate political strategy formulation: a model of approach, participation, and strategy decisions. Academy of Management Review, v. 24, n. 4, p. 825-842, 1999.

HOSKISSON, R. E.; EDEN, L.; LAU, C. M.; WRIGHT, M. Strategy in emerging economies. Academy of Management Journal, v. 43, n. 3, p. 249-267, 2000.

HOUSTON, J. F.; JIANG, L.; LIN, C.; MA, Y. Political connections and the cost of bank loans. Journal of Accounting Research, v. 52, n. 1, p. 193-243, 2014.

INOUE, C.; LAZZARINI, S.; MUSACCHIO, A. Leviathan as a minority shareholder: firm-level implications of equity purchases by the State. Academy of Management Journal, v. 56, n. 6, p. 1775-1801, 2013.

JIANG, C. The nature of political connections and firma value. In: CHOI, J. J.; DOW, S. (Eds.), Institutional approach to global corporate governance: business systems and beyond. International Finance Review, v. 9, p. 461-494, 2008.

KHANNA, T.; PALEPU, K. Why focused strategies may be wrong for emergingmarkets. Harvard Business Review, v. 75, n. 4, p. 41-51, 1997.

KHWAJA, A. I.; MIAN, A. Do lenders favor politically connected firms? Rent provision in an emerging financial market. The Quarterly Journal of Economics, v. 120, n. 4, p. 1371-1411, 2005.

LAZZARINI, S. G.; MUSACCHIO, A. Leviathan as a minority shareholder: a study of equity purchases by the Brazilian National Development Bank (BNDES), 1995-2003. Available at SSRN 1713429, 2010. 
LAZZARINI, S. G.; MUSACCHIO, A.; BANDEIRA-DE-MELLO, R.; MARCON, R. What do development banks do? Evidence from Brazil, 2002-2009. Harvard Business School, Working Paper, v. 12, n. 47, p. 12-047, 2011.

LI, H.; MENG, L.; WANG, Q.; ZHOU, L. A. Political connections, financing and firm performance: evidence from chinese private firms. Journal of Development Economics, v. 87, n. 2, p. 283-299, 2008.

LOPES FÁVERO, L. P. Dados em painel em contabilidade e finanças: teoria e aplicação. Brazilian Business Review - BBR, v. 10, n. 1, p. 131-156, 2013.

MUSACCHIO, A.; LAZZARINI, S. G. Reinventando o capitalismo de Estado: o Leviata nos negócios: Brasil e outros países. São Paulo: Portfolio-Penguin, 2015.

MYERS, S. C.; MAJLUF, N. S. Corporate financing and investment decisions when firms have information that investors do not have. Journal of Financial Economics, v.13, n. 2, p. 187-221, 1984.

MENOZZI, A.; GUTIÉRREZ URTIAGA, M.; VANNONI, D. Board composition, political connections, and performance in state-owned enterprises. Industrial and Corporate Change, v. 21, n. 3, p. 671-698, 2011.

NONNENBERG, M. J. B.; MENDONÇA, M. J. C. Determinantes dos investimentos diretos externos em países em desenvolvimento. Estudos Econômicos, v. 35, n. 4, p. 631-655, 2005.

NORTH, D. C. Institutions, institutional change and economic performance. Cambridge, MA: Cambridge University Press, 1990.

NORTH, D. C.; THOMAS, R. P. The rise of the western world: a new economic history. New York: Cambridge University Press, 1972.

NUNES, M. S.; COSTA JÚNIOR, N.; MEURER, R. A relação entre o mercado de ações e as variáveis macroeconômicas: uma análise econométrica para o Brasil. Revista Brasileira de Economia, v. 59, n. 4, p. 585-607, 2005.

OKHMATOVSKIY, I. Performance implications of ties to the government and SOEs: A political embeddedness perspective. Journal of Management Studies, v. 47, n. 6, p. 1020-1047, 2010.

PROCIANOY, J. L.; SCHNORRENBERGER, A. A influência da estrutura de controle nas decisões de estrutura de capital das companhias brasileiras. Revista Brasileira de Economia, v. 58, n. 1, p. 122-146, 2004.

RAJAN, R.; ZINGALES, L. The great reversals: the politics of financial development in the 20th century. Journal of Financial Economics, v. 69, n. 1, p. 5-50, 2003.

SAMUELS, D. J. Money, elections, and democracy in Brazil. Latin American Politics and Society, v. 43, n. 2, p. 27-48, 2001.

TITMAN, S.; WESSELS, R. The determinants of capital structure choice. Journal of Finance, v. 43, n. 1, p. 1-19, 1988.

VENKATRAMAN, N.; RAMANUJAM, V. Measurement of business performance in strategy research: a comparison of approaches. Academy of Management Review, v. 11, n. 4, p. 801-814, 1986.

XAVIER, W. G.; BANDEIRA-DE-MELLO, R.; MARCON, R. Institutional environment and Business Groups' resilience in Brazil. Journal of Business Research, v. 67, n. 5, p. 900-907, 2014. 